Kemampuan Berpikir Logis....(Ety Septiani)

\title{
KEMAMPUAN BERPIKIR LOGIS MAHASISWA PENDIDIKAN MATEMATIKA PADA MATA KULIAH ANALISIS REAL
}

\author{
Oleh: Ety Septiati \\ (Dosen Universitas PGRI Palembang) \\ Email : etyseptiati@univpgri-palembang.ac.id
}

\begin{abstract}
Abstrak
Penelitian ini bertujuan untuk menggambarkan kemampuan berpikir logis matematis mahasiswa pendidikan matematika setelah mengikuti perkuliahan Analisis Real. Penelitian ini termasuk jenis penelitian kuantitatif yang menggunakan metodologi penelitian deskriptif. Kemampuan berpikir logis mahasiswa dilihat dari nilai tes yang diperoleh dalam penyelesaian soal yang telah disusun dengan mengacu pada indikator kemampuan berpikir logis matematis. Teknik analisis data yang digunakan dalam penelitian ini meliputi reduksi data, penyajian data, perhitungan statistika deskripstif dan penarikan kesimpulan/verifikasi. Hasil penelitian menunjukkan bahwa secara keseluruhan kemampuan berpikir logis matematis mahasiswa berada pada kategori rendah. Indikator tertinggi yang berhasil diraih adalah pada indikator 4, menetapkan kombinasi beberapa variabel dan berada pada kategori sedang. Sedangkan indikator terendah yaitu menarik kesimpulan atau membuat perkiraan atau prediksi berdasarkan korelasi antara dua variabel yang berada pada kategori sangat rendah.
\end{abstract}

Kata Kunci : Kemampuan Berpikir Logis Matematis, Analisis Real

\section{MATHEMATICAL LOGICAL THINKING ABILITY OF MATHEMATICS EDUCATION STUDENTS IN REAL ANALYSIS LECTURES}

\begin{abstract}
This study aims to describe the mathematical logical thinking ability of mathematics education students after attending Real Analysis lectures. This research includes the type of quantitative research using descriptive research methodology. The students' logical thinking ability is seen from the test scores obtained in the solution of the questions that have been prepared with reference to the mathematical logical thinking ability indicator. Data analysis techniques used in this study include data reduction, data presentation, descriptive statistical calculations and drawing conclusions / verification. The results showed that overall students' mathematical logical thinking ability was in the low category. The highest indicator achieved is on indicator 4, establishing a combination of several variables and being in the moderate category. While the lowest indicator
\end{abstract}


Wahana Didaktika Vol. 16 No.2 Mei 2018 : 207-221

is to draw conclusions or make estimates or predictions based on the correlation between two variables that are in very low category.

Keywords: Mathematical Logical Thinking Ability, Real Analysis

\section{A. PENDAHULUAN}

Dalam pembelajaran matematika, kemampuan penalaran, pembuktian, komunikasi dan koneksi lebih ditekankan pada berpikir logis. Berpikir logis memuat kegiatan penalaran logis dan kegiatan matematika lainnya seperti: pemahaman, koneksi, komunikasi, dan penyelesaian masalah secara logis (Sumarmo, 2012). Kemampuan berfikir logis merupakan kemampuan seseorang dalam menyelesaikan masalah tidak hanya berdasar pada prosedur yang ada, akan tetapi memiliki landasan kebenaran yang kuat dari prosedur tersebut (Syawahid, 2015:138). Menurut Sumarmo (2012:19) kemampuan berpikir logis meliputi kemampuan: 1) menarik kesimpulan atau membuat, perkiraan dan interpretasi berdasarkan proporsi yang sesuai, 2)menarik kesimpulan atau membuat perkiraan dan prediksi berdasarkan peluang, 3) Menarik kesimpulan atau membuat perkiraan atau prediksi berdasarkan korelasi antara dua variabel, 4) Menetapkan kombinasi beberapa variabel, 5) Analogi adalah menarik kesimpulan berdasarkan keserupaan dua proses, 6) Melakukan pembuktian, 7) Menyusun analisa dan sintesa beberapa kasus.

Kemampuan berpikir logis memerankan peranan penting dalam pemahaman untuk menyelesaikan soal matematika. Menurut Syafmen \& Marbun (2014) pemahaman konsep yang tidak didukung oleh kemampuan berpikir logis akan mengakibatkan siswa mempunyai intuisi yang baik tentang suatu konsep tapi tidak mampu menyelesaikan suatu masalah. Hal ini sejalan dengan beberapa hasil penelitian (dalam Tuna, 2013:83) yang menunjukkan bahwa kemampuan berpikir logis memiliki peran mendasar dalam kinerja akademik siswa dan konstruksi konsep mereka. Oleh karena itu, sangatlah wajar Erihadiana (2013:60) berpendapat bahwa kemampuan berpikir sistematis, terutama berpikir logis dan 
Kemampuan Berpikir Logis....(Ety Septiani)

ilmiah harus dilatihkan dan dikuasai dengan baik sejak menjadi mahasiswa keguruan/calon guru.

Salah satu matakuliah yang wajib ditempuh oleh mahasiswa pendidikan Matematika adalah Analisis Real. Melalui perkuliahan Analisis Real, mahasiswa diharapkan mampu: a) memiliki pengetahuan dasar analisis matematika, khususnya tentang bilangan, barisan, fungsi, limit, dan turunan, b) bernalar secara logis dan mengekspresikan hasil pernalarannya secara tertulis, sistematis dan rigorous. Mata kuliah ini membekali mahasiswa kemampuan bernalar yang merupakan salah satu dari kemampuan matematika (mathematic competence). Pengetahuan prosedural mahasiswa yang diperoleh dari mata kuliah Kalkulus 1,2 dan lanjutan akan diperdalam pada mata kuliah analisis real agar mahasiswa tidak hanya berfikir prosedural (procedural thinking) akan tetapi juga memiliki kemampuan berfikir logis (logically thinking) (Syawahid, 2015:142).

Matakuliah Analisis Real adalah salah satu mata kuliah yang cukup ketat dalam memberlakukan sistem deduktif aksiomatik sehingga cukup ditakuti bagi sebagian besar mahasiswa. Pemahaman definisi formal sampai pembuktian dan sifat-sifatnya merupakan tantangan tersediri bagi mahasiswa. Permasalahan yang paling menonjol dihadapi dalam perkuliahan analisis real adalah terjadinya miskonseps mahasiswa terhadap materi sehingga menyulitkan dalam pembuktian (Wahyuni, 2017:148). Di samping itu juga, keberhasilan seseorang menguasai Analisis Real yang notabene adalah matematika murni di samping Aljabar abstrak, sangat bergantung pada ketajaman menganalisis dengan menggunakan alur logika yang absah (Wuryanto, 2011:37). Hasil penelitian Wuryanto (2011) memberi petunjuk bahwa pembelajaran Analisis Real 1 yang disertai tindakan berupa pemberdayaan penalaran berasaskan prinsip reductio ad absurdum, berhasil menekan hambatan belajar mahasiswa dalam mengerjakan dengan benar soal-soal pembuktian suatu tautologi. 
Berdasarkan uraian di atas, penulis tertarik untuk menggambarkan kemampuan berpikir logis mahasiswa matematika setelah mengikuti perkuliahan Analisis Real.

\section{B. METODOLOGI PENELITIAN}

Penelitian ini termasuk jenis penelitian kuantitatif yang menggunakan metodologi penelitian deskriptif. Hal yang dideskripsikan dalam penelitian ini adalah kemampuan berpikir logis matematis. Kemampuan berpikir logis mahasiswa dilihat dari nilai tes yang diperoleh dalam penyelesaian soal yang telah disusun dengan mengacu pada indikator kemampuan berpikir logis matematis menurut Sumarmo (2012). Subjek dalam penelitian ini adalah mahasiswa semester V(lima) yang sedang mengikuti mata kuliah Analisis Real.

Prosedur yang digunakan dalam penelitian ini terdiri dari tiga tahap, yaitu : 1) Tahap Perencanaan (Pemilihan subjek penelitian, Menyusun kisi-kisi soal tes yang sesuai dengan indikator kemampuan berpikir logis, Validasi instrumen, dilakukan kepada pakar atau dosen senior yang sedang atau pernah mengampu mata kuliah Analisis Real); 2) Tahap Pelaksanaan Penelitian (tes yang mengacu pada indikator kemampuan berpikir logis; 3) Tahap Pelaporan (analisis data dan pembahasan untuk diambil suatu kesimpulan dari hasil penelitian). Teknik analisis data yang digunakan dalam penelitian ini meliputi reduksi data, penyajian data, perhitungan statistika deskripstif dan penarikan kesimpulan/verifikasi. Dalam pemberian skor kemampuan berpikir logis, peneliti menggunakan rubrik yang dikeluarkan oleh Indiana University East School of Natural Sciences and Math “Assessment Rubric” (https://sumarlinmankonda.files.wordpress.com).

Skor yang diperoleh dari hasil tes, dikonversi menjadi nilai dengan rentang 0 - 100, dengan menggunakan rumus:

$$
\text { Nilai }=\frac{\text { skor } \text { yang diperoleh }}{\text { skor total }} \times 100
$$


Data hasil tes kemampuan berpikir logis matematis mahasiswa tersebut dikelompokkan berdasarkan kategori pada Tabel 1.

Tabel 1. Kategori Kemampuan Berpikir Logis

(Modifikasi Arikunto, 2010)

\begin{tabular}{|c|c|}
\hline Rentang Nilai & Kategori \\
\hline $81-100$ & Sangat Tinggi \\
\hline $61-80$ & Tinggi \\
\hline $41-60$ & Sedang \\
\hline $21-40$ & Rendah \\
\hline $0-20$ & Sangat Rendah \\
\hline
\end{tabular}

\section{HASIL DAN PEMBAHASAN}

Data-data yang diperoleh dari penelitian disajikan pada tabel 2, tabel 3 dan tabel 4.

Tabel 2. Distribusi Frekuensi Nilai Tes Kemampuan Berpikir Logis Mahasiswa

\begin{tabular}{|c|c|c|c|}
\hline \multicolumn{1}{|c|}{ Mahasiswa } \\
\hline Rentang Nilai & f & $\%$ & Kategori \\
\hline $81-100$ & 0 & 0 & Sangat Tinggi \\
\hline $61-80$ & 0 & 0 & Tinggi \\
\hline $41-60$ & 6 & 21 & Sedang \\
\hline $21-40$ & 14 & 48 & Rendah \\
\hline $0-20$ & 9 & 31 & Sangat Rendah \\
\hline Jumlah & $\mathbf{2 9}$ & $\mathbf{1 0 0}$ & \\
\hline
\end{tabular}

Berdasarkan tabel di atas, diketahui bahwa frekwensi nilai tertinggi berada dalam rentang 21-40 yang masuk kategori rendah.

\section{Tabel 3. Deskripsi Statistik Nilai Tes Kemampuan Berpikir Logis Mahasiswa}

\begin{tabular}{|l|c|}
\hline \multicolumn{1}{|c|}{ Statistik Deskriptif } & Nilai \\
\hline Rata-rata & 31,6 \\
\hline Standar Deviasi & 12,2 \\
\hline Nilai Maksimum & 51,9 \\
\hline Nilai Minimum & 10,0 \\
\hline Modus & 31,9 \\
\hline
\end{tabular}

Berdasarkan Tabel 3, diperoleh informasi bahwa kemampuan berpikir logis matematis mahasiswa berada pada rentang nilai 10 - 51,9, yaitu kategori sangat rendah sampai dengan sedang. Nilai yang paling banyak diperoleh adalah 31,9 
(kategori rendah). Data menyebar mengikuti distribusi normal, terlihat dari nilai rata-rata dan modus yang berdekatan, dengan standar deviasi 12,2.

Berdasarkan tabel 4 diketahui bahwa secara rata-rata indikator tertinggi yang berhasil diraih adalah pada indikator 4 , menetapkan kombinasi beberapa variabel dan berada pada kategori sedang. Sedangkan indikator terendah yaitu menarik kesimpulan atau membuat perkiraan atau prediksi berdasarkan korelasi antara dua variabel yang berada pada kategori sangat rendah.

Tabel 4. Rata-Rata Nilai Kemampuan Berpikir Logis Mahasiswa Per-Indikator

\begin{tabular}{|c|l|c|c|}
\hline No & \multicolumn{1}{|c|}{ Indikator Kemampuan Berpikir Logis } & $\begin{array}{c}\text { Rata- } \\
\text { rata }\end{array}$ & Kategori \\
\hline 1 & $\begin{array}{l}\text { Menarik kesimpulan atau membuat perkiraan dan } \\
\text { interpretasi berdasarkan proporsi yang sesuai. }\end{array}$ & 14,5 & $\begin{array}{c}\text { Sangat } \\
\text { Rendah }\end{array}$ \\
\hline 2 & $\begin{array}{l}\text { Menarik kesimpulan atau membuat perkiraan dan } \\
\text { prediksi berdasarkan peluang }\end{array}$ & 44,8 & Sedang \\
\hline 3 & $\begin{array}{l}\text { Menarik kesimpulan atau membuat perkiraan atau } \\
\text { prediksi berdasarkan korelasi antara dua variabel }\end{array}$ & 8,3 & $\begin{array}{c}\text { Sangat } \\
\text { Rendah }\end{array}$ \\
\hline 4 & Menetapkan kombinasi beberapa variable & 48,3 & Sedang \\
\hline 5 & $\begin{array}{l}\text { Analogi adalah menarik kesimpulan berdasarkan } \\
\text { keserupaan dua proses. }\end{array}$ & 17,9 & $\begin{array}{c}\text { Sangat } \\
\text { Rendah }\end{array}$ \\
\hline 6 & Melakukan pembuktian & 42,6 & Sedang \\
\hline 7 & Menyusun analisa dan sintesa beberapa kasus & 44,8 & Sedang \\
\hline
\end{tabular}

Pembahasan pada setiap indikator dapat diuraikan sebagai berikut:

\section{Menarik Kesimpulan/Membuat Perkiraan dan Interpretasi Berdasarkan Proporsi yang Sesuai (Indikator ke-1)}

Nilai rata-rata pada indikator ini adalah sebesar 14,5 dan berada pada kategori sangat rendah. Berdasarkan analisis data skor yang paling banyak diperoleh mahasiswa adalah 0 yaitu sebesar 68,9\% dari sampel, artinya jawaban menunjukkan logika tidak ada atau sangat tidak lengkap untuk mengevaluasi. Pertanyaan untuk mengukur indikator ini diajukan pada soal no. 1, yaitu membuktikan kekonvergenan suatu barisan dengan menggunakan definisi formal dari barisan konvergen. Meskipun materi yang ditanyakan merupakan materi bagian akhir pada matakuliah Analisis Real, akan tetapi hampir 20 orang 
Kemampuan Berpikir Logis...(Ety Septiani)

mahasiswa tidak menjawab pertanyaan ini. Sisanya, yaitu 9 sampel menjawab dengan cara menghitung limit barisannya saja. Berdasarkan kunci jawaban, mahasiswa diharapkan dapat membuat interpretasi berdasarkan proporsi yang sesuai dengan definisi formal dari barisan konvergen. Mahasiswa diharapkan dapat menunjukkan bahwa memang terdapat bilangan Asli $\mathbf{N}$ yang memenuhi kriteria yang tertera pada definisi. Cuplikan jawaban mahasiswa pada indikator ke-1 ditampilkan pada Gambar 1.

\section{Menarik Kesimpulan atau Membuat Perkiraan dan Prediksi} Berdasarkan Peluang (Indikator ke-2).

Skor rata-rata pada indikator ini adalah sebesar 44,8 dan berada pada kategori sedang. Indikator ini diukur melalui pertanyaan pada soal no. 2, dimana mahasiswa diminta membuktikan bahwa $1>0$. Meskipun sebagian besar mahasiswa mampu membuktikan pernyataan $1>0$, akan tetapi pada langkah membuat perkiraan dan prediksi berdasarkan peluang belum dilakukan dengan baik. Sebanyak $72.4 \%$ atau 21 orang mahasiswa mendapat skor 3 untuk indikator ini. Artinya, 72.4\% sampel telah memiliki logika yang baik dan penalaran secara keseluruhan tapi ada satu langkah besar yang hilang, dimana mahasiswa tidak menuliskan sifat trikotomi yang dimiliki oleh bilangan real. Jawaban yang tepat adalah seharusnya mahasiswa menuliskan ketiga kemungkinan yang terjadi antara 0 dan $1(0<1$ atau $0=1$ atau $0>1)$. Berdasarkan 3 kemungkinan inilah mahasiswa diharapkan mampu memprediksi untuk mendapatkan kesimpulan yang tepat. Jawaban mahasiswa pada indikator ke-2, ditampilkan pada Gambar 2.

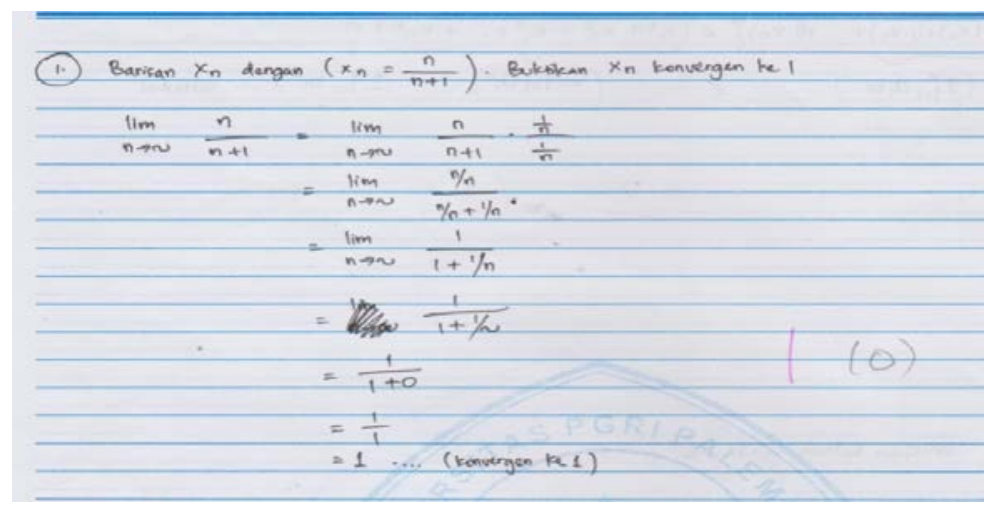




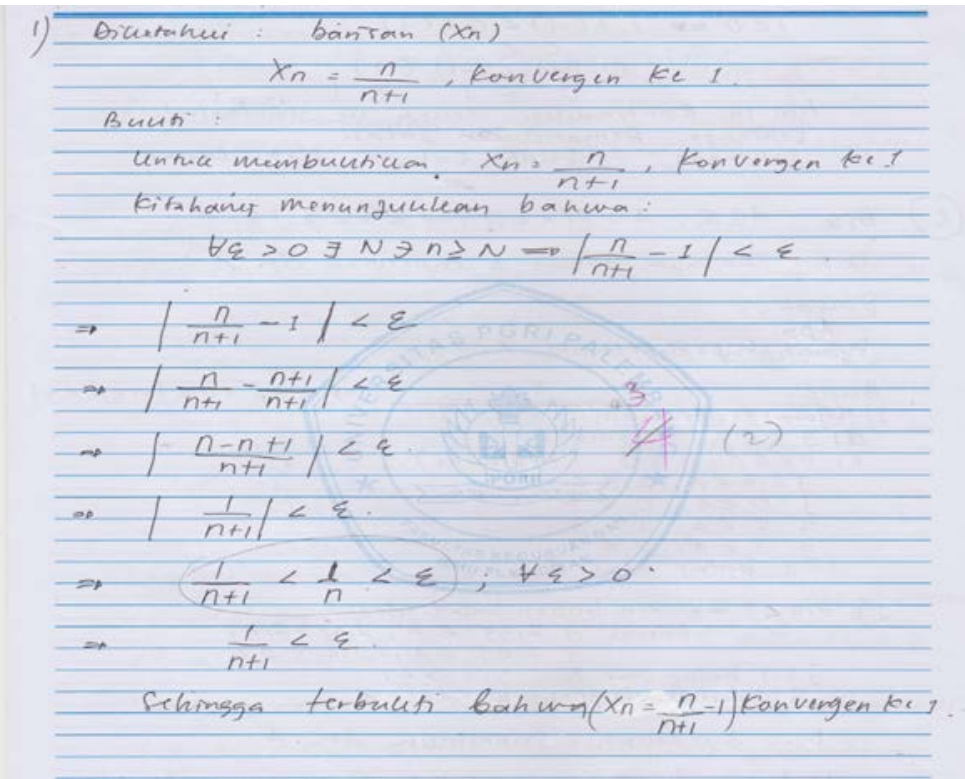

Gambar 1. Beberapa Jawaban Mahasiswa pada Soal no. 1

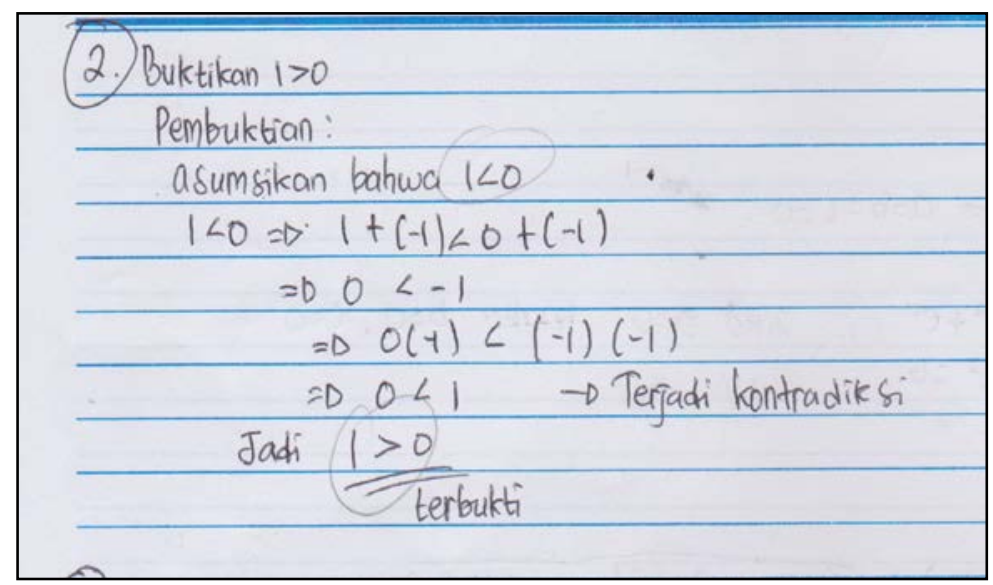

Gambar 2. Kesalahan Jawaban Mahasiswa pada Indikator ke-2

\section{Menarik Kesimpulan atau Membuat Perkiraan atau Prediksi Berdasarkan Korelasi Antara Dua Variabel (Indikator ke-3)}

Nilai rata-rata pada indikator ini adalah sebesar 8,3 yang artinya sangat rendah. Indikator ke-3 terdapat pada soal no. 3, dimana mahasiswa diminta untuk membuktikan bahwa jika $a^{2}+b^{2}+c^{2}=0$ maka $a=b=c=0$. Sebanyak 20 sampel mendapat skor 0 untuk indikator ini, yaitu 68.97\% mahasiswa tidak menjawab pertanyaan pada nomor ini. Meskipun demikian, terdapat 1 mahasiswa 
Kemampuan Berpikir Logis....(Ety Septiani)

mendapatkan skor 4 dan 8 mahasiswa mendapat skor 1. Berdasarkan kunci jawaban, pertanyaan yang diajukan dapat diselesaikan dengan cara kontradiksi (pembuktian dengan kontradiksi). Pembuktian melalui kontradiksi adalah argumen logika yang dimulai dengan suatu asumsi, lalu dari asumsi tersebut diturunkan suatu hasil yang absurd, tidak masuk akal, atau kontradiktif, sehingga dapat diambil kesimpulan bahwa asumsi tadi adalah salah (dan ingkarannya benar). Dalam disiplin matematika dan logika, pembuktian melalui kontradiksi merujuk secara khusus kepada argumen dimana sebuah kontradiksi dihasilkan dari suatu asumsi (sehingga membuktikan asumsi tadi salah). Akan tetapi, pembuktian dengan kontradiksi tidaklah mudah dilakukan. Hal ini dikarenakan tidaklah mudah menentukan teknik pembuktian yang tepat untuk menyelesaikan suatu persoalan terkait pembuktian. Menurut Harini (2014:36), miskonsepsi mahasiswa dalam Analisis Real terjadi dalam hal menentukan teknik pembuktian. Mahasiswa biasanya mengalami kebingungan dalam menentukan langkah awal ketika akan melakukan pembuktian. Padahal dalam pembuktian kontradiksi, langkah awal merupakan langkah paling penting.

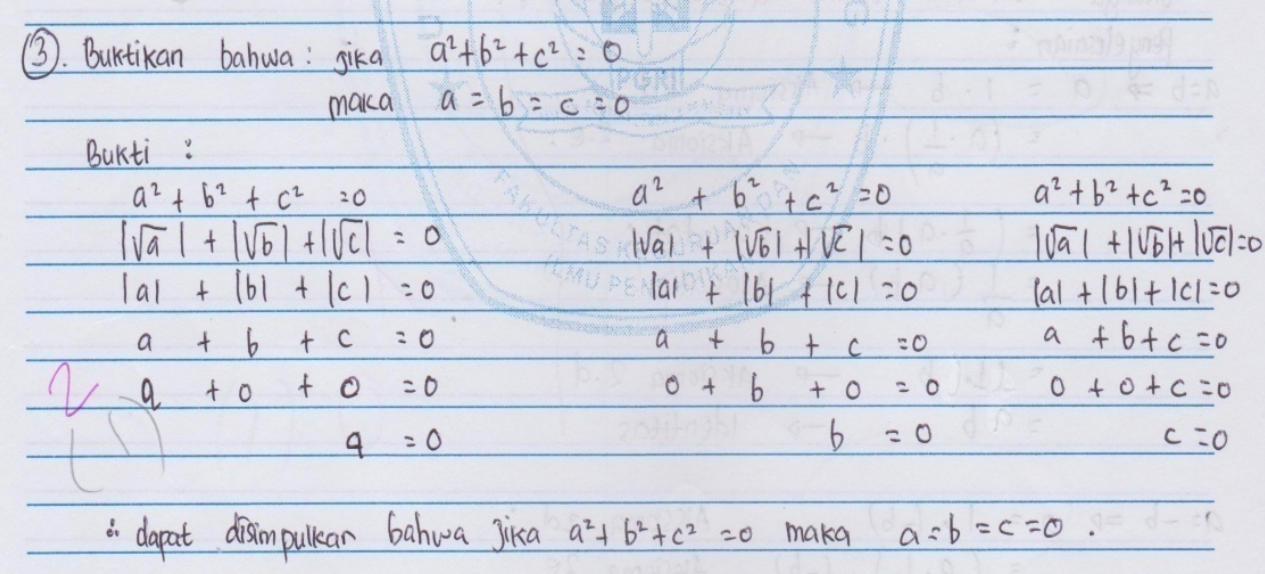




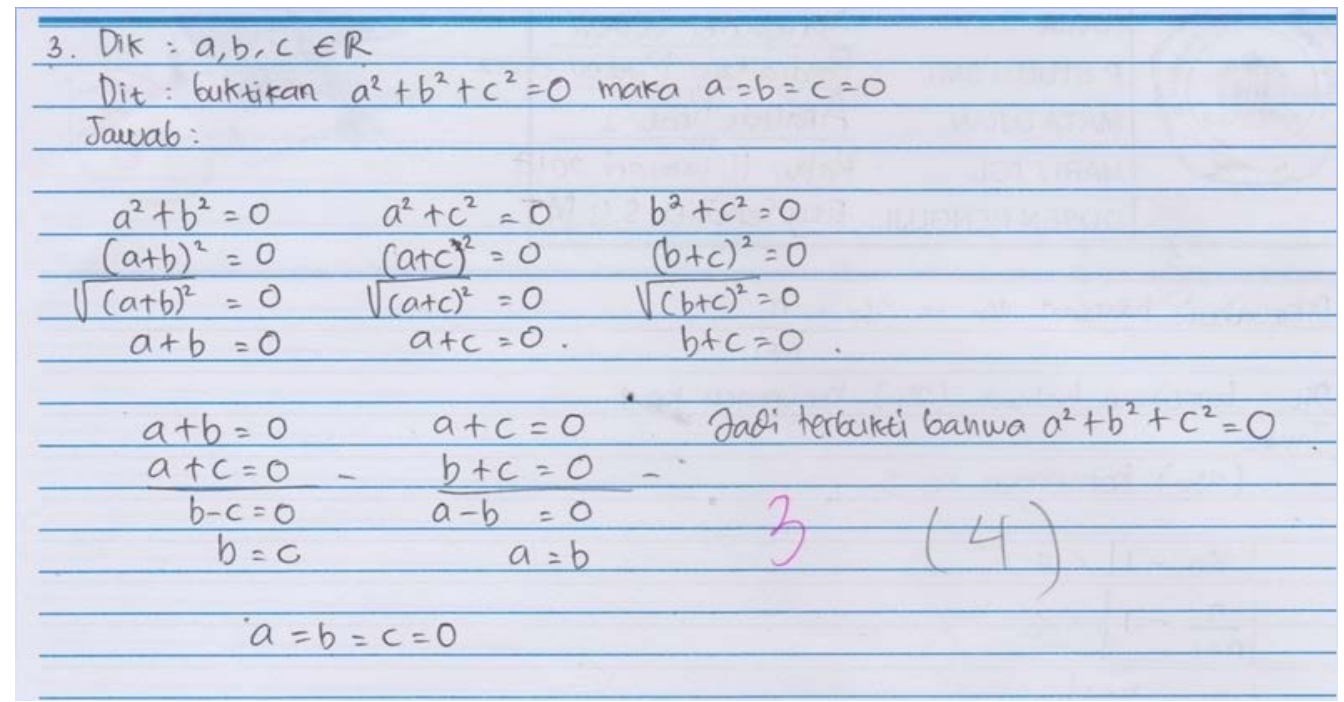

\section{Menetapkan kombinasi beberapa variabel (Indikator ke-4)}

Nilai rata-rata pada indikator ini adalah sebesar 48,3 dan termasuk kategori sedang. Indikator ini diukur melalui jawaban mahasiswa pada soal no. 4, yaitu: Diketahui $a, b \in \Re$ sehingga $a a=b b$. Buktikan bahwa $a=b$ atau $a=-b$. Untuk bisa menjawab dengan benar digunakan sifat Field (lapangan). Setelah dianalisis diperoleh 12 orang mahasiswa atau 41.38\% mendapat skor 5 untuk indikator ini, 1 orang mendapat skor 4, 6 orang mendapat skor 1 dan 10 orang mendapat skor 0. Sebagian besar kekeliruan yang dilakukan dalam menjawab soal adalah mahasiswa tidak memanfaatkan apa yang diketahui dari soal sebagai langkah awal untuk melakukan pembuktian. Cuplikan jawaban mahasiswa pada soal no. 4 disajikan pada Gambar 4.

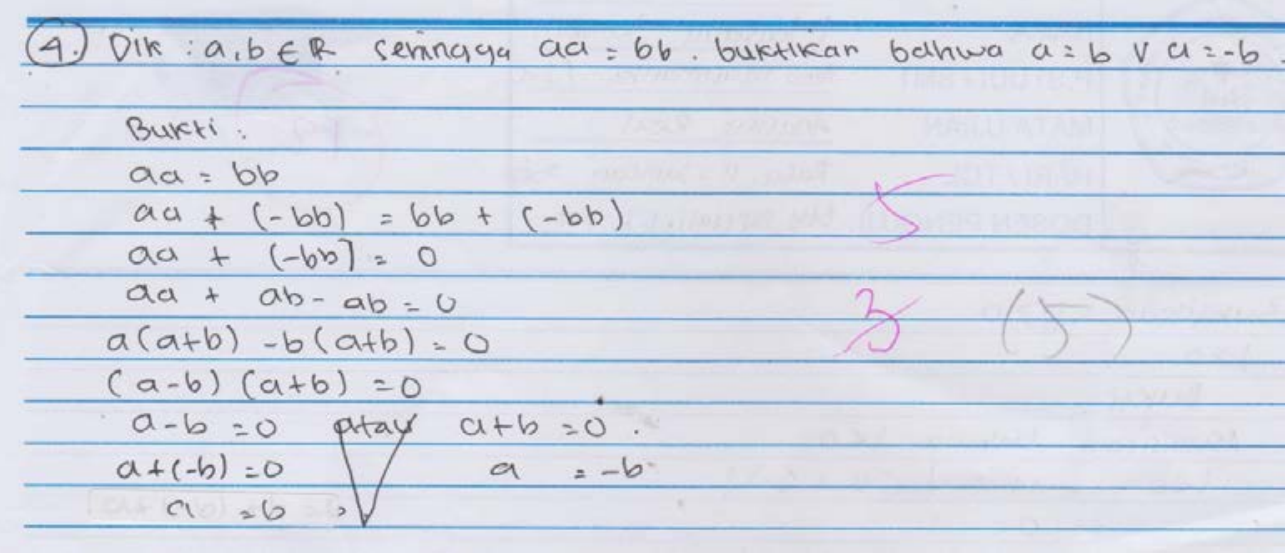


Kemampuan Berpikir Logis....(Ety Septiani)

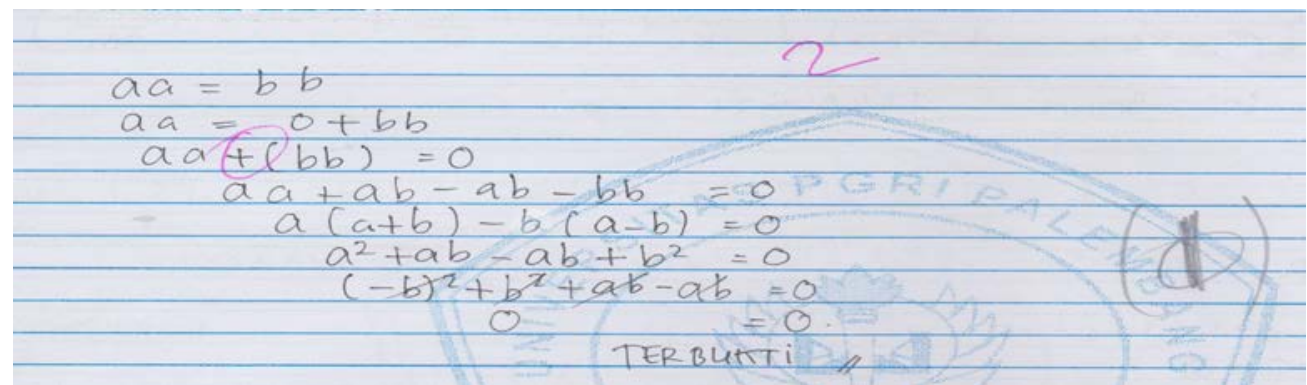

Gambar 4. Beberapa Jawaban Mahasiswa pada soal no. 4

\section{Analogi atau Menarik Kesimpulan Berdasarkan Keserupaan Dua Proses (Indikator ke-5)}

Nilai rata-rata pada indikator ini adalah sebesar 17,9 dan masuk kategori sangat rendah. Indikator ini diukur melalui jawaban mahasiswa pada soal no. 5, yaitu membuktikan $\left(x_{1}+x_{2}+x_{3}+\cdots+x_{n}\right) \leq \sqrt{\left(x_{1}{ }^{2}+x_{2}{ }^{2}+x_{3}{ }^{2}+\cdots+x_{n}{ }^{2}\right) n}$ dengan menggunakan Ketaksamaan Cauchy Schwarz. 51,72\% responden (15 orang) mendapat skor 0 untuk indikator ini, meskipun ada 3 orang yang mendapat skor 5 dan 11 orang mendapat skor 1. Berdasarkan kunci jawaban, pembuktian ini dilakukan dengan mengkonstruksi unsur-unsur yang menyusun Ketaksamaan Cauchy Schwarz $\left(\sum_{i=1}^{n} a_{i} b_{i}\right)^{2} \leq\left(\sum_{i=1}^{n} a_{i}{ }^{2}\right)\left(\sum_{i=1}^{n} b_{i}{ }^{2}\right) ; a_{i_{i}} b_{i} \in \Re ; i=1,2,3, \ldots n$, dalam hal ini $a_{i}=x_{i}$ dan $b_{i}=1 ; \forall i=1,2,3, \ldots$. Dituntut pemahaman yang baik untuk bisa menentukan nilai $a_{i}$ dan $b_{i}$ yang tepat dan ini yang tidak bisa dilakukan dengan baik oleh mahasiswa. Menentukan nilai $a_{i}$ dan $b_{i}$ yang tepat adalah langkah kunci untuk bisa mengkonstruksi dan melakukan pembuktian pada kasus ini. Soal-soal yang mirip dengan kasus ini telah dibahas dalam perkuliahan. Diharapkan mahasiswa mampu menganalogikan kasus-kasus yang telah dibahas dalam perkuliahan pada kasus ini. Akan tetapi justru tidak demikian yang terjadi. Berdasarkan penelusuran lebih lanjut, diketahui bahwa konsep deret dan penggunaan notasi sigma tidak dipahami dengan baik oleh mahasiswa. Cuplikan jawaban mahasiswa pada soal nomor 5 disajikan pada Gambar 5. 
Wahana Didaktika Vol. 16 No.2 Mei 2018 : 207-221

\section{Melakukan Pembuktian (Indikator ke-6)}

Indikator melakukan pembuktian diajukan pada setiap pertanyaan yang diajukan pada soal tes, yaitu sebanyak 6 soal. Setelah dianalisis, modus data ada pada skor 2 dan 3, masing-masing sebesar 37,9\%. Sisanya sebesar 24,1\% atau sebanyak 7 mahasiswa mendapat skor 1 . Artinya, jawaban siswa untuk indikator ini sudah benar secara logika, namun perlu penyempurnaan dalam menuliskan argumen sehingga langkah-langkah pendukungnya menjadi lengkap. Menurut Hernadi, (2008:13) belajar matematika dengan cara memahami bukti tidaklah mudah. Dibutuhkan waktu untuk memahami matematika sebagai bahasa logika. Juga, dibutuhkan wawasan matematika yang luas untuk belajar membuktikan fakta-fakta yang lebih rumit. Di dalam bukti termuat nilai-nilai strategis yang dapat melatih kita berpikir secara logis. Hal ini merupakan tantangan tersendiri bagi peneliti dalam mengajarkan materi perkuliahan matematika yang sifatnya bukan berhitung atau bisa dikatakan lebih banyak membahas permasalahan yang sifatnya non rutin, seperti pada mata kuliah Analisis Real ini. Tarhadi (2006:132) berpendapat bahwa pembuktian bukan merupakan materi yang tercantum dalam tubuh pengetahuan matematika sendiri tetapi merupakan metoda. Pembuktian tidak terletak pada kawasan ontologi matematika tetapi terletak pada kawasan epistemologi matematika. Pembuktian diajarkan secara implisit pada pendidikan tatap muka melalui demonstrasi. Mahasiswa dan pengajar dapat berdialog mengenai langkah pembuktian.

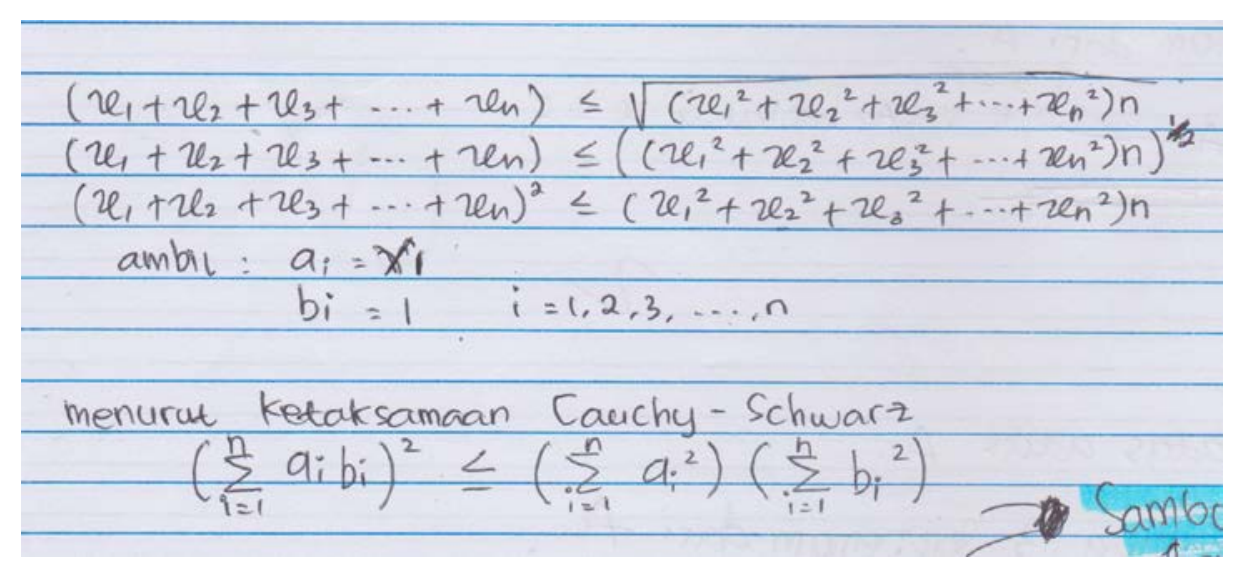




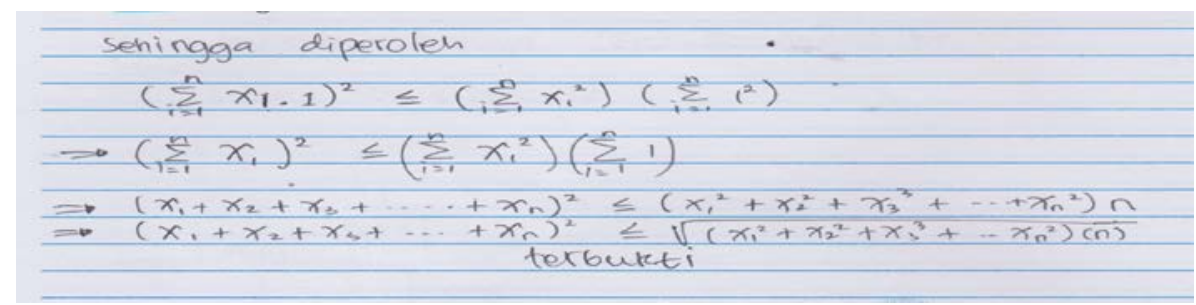

\section{Gambar 5. Cuplikan Jawaban Mahasiswa yang mendapat Skor 5}

\section{Menyusun analisa dan sintesa beberapa kasus (Indikator ke-7)}

Nilai rata-rata pada indikator ini adalah sebesar 44,8 dan termasuk kategori sedang. Indikator ini diukur melalui jawaban mahasiswa pada soal no. 6, yaitu: menunjukkan bahwa 3 supremum dari A, jika diketahui $A \subseteq \mathfrak{R}$, $A=\{(x \in \Re \mid-1 \leq x<3)\}$. Skor tertinggi, yaitu 5 diperoleh 3 orang mahasiswa. Sedangkan skor yang paling banyak diperoleh mahasiswa adalah 3, yaitu diraih oleh 11 mahasiswa atau sebesar 37,9\% dari sampel. Berdasarkan kunci jawaban, ada 2 hal yang harus diperlihatkan untuk menyelesaikan soal tersebut, yaitu: 1) Menunjukkan 3 sebagai batas atas A dan 2) $\forall b \in$ batas atas A maka $3 \leq b$. Kekeliruan yang banyak dilakukan adalah ada beberapa langkah kecil yang tidak dilakukan oleh mahasiswa, seperti memperlihatkan bukti bahwa 3 batas atas A atau memperlihatkan bukti bahwa $\forall b \in$ batas atas $A$ maka $3 \leq b$, meskipun secara keseluruhan sudah memperlihatkan penalaran yang tepat. Cuplikan jawaban mahasiswa pada soal no.6 disajikan pada Gambar 6.

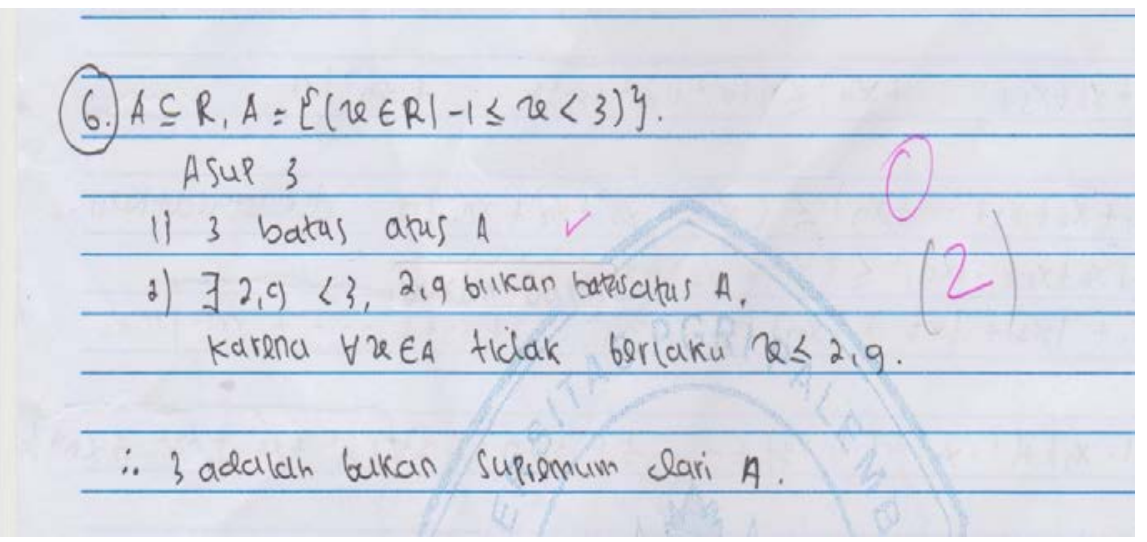

Gambar 6. Kesalahan Jawaban Mahasiswa pada Soal no. 6 
Wahana Didaktika Vol. 16 No.2 Mei 2018 : 207-221

\section{SIMPULAN}

Berdasarkan hasil penelitian dapat disimpulkan bahwa kemampuan berpikir logis mahasiswa matematika setelah mengikuti perkuliahan Analisis Real tergolong rendah. Indikator tertinggi yang berhasil diraih adalah pada indikator 4, menetapkan kombinasi beberapa variabel dan berada pada kategori sedang. Sedangkan indikator terendah yaitu menarik kesimpulan atau membuat perkiraan atau prediksi berdasarkan korelasi antara dua variabel yang berada pada kategori sangat rendah.

\section{DAFTAR PUSTAKA}

Arikunto, Suharsimi. 2010. Dasar-Dasar Evaluasi Pendidikan. Jakarta: Bumi Aksara.

Erihadiana, Mohamad. 2013. Pembelajaran Penelitian Tindakan Kelas di Perguruan Tinggi Islam. Vol. XXVIII No. 1 2013/1434.

Harini, Astawa \& I Gusti Ayu Made Srinadi. 2014. Eksplorasi Miskonsepsi Mahasiswa dalam Pengembangan Buku Teks Analisis Real Bermuatan Peta Pikiran. Makalah disajikan pada Seminar Nasional Sains dan Teknologi Denpasar-Bali, 18 - 19 September 2014.

Hernadi, Julan. 2008. Metode Pembuktian dalam Matematika. Jurnal Pendidikan Matematika, Volume 2 Nomor 1, Januari 2008.

Sumarmo, Utari, dkk. 2012. Kemampuan dan Disposisi Berpikir Logis, Kritis dan Kreatif Matematik (Eksperimen Terhadap Siswa SMA Menggunakan Pembelajaran Berbasis Masalah dan Stratge Think Talk Write). Jurnal Pengajaran MIPA, Volume 17 (Nomor 1, April 2012). halaman.17-33.

Syafmen, Wardi \& R.H. Marbun. 2014. Analisis Kemampuan Berpikir Logis Siswa Gaya Belajar Tipe Thinking Dalam Memecahkan Masalah $\begin{array}{llll}\text { Matematika.Retrieved } & 19 & \text { Mei } & 2016\end{array}$ http://journal.unbari.ac.id/index.php/JIP/article/view/127.

Syawahid, M. 2015. Kemampuan Berpikir Formal Mahasiswa. Beta Jurnal Pendidikan Matematika Vol. 8 No.2 (Nov) 2015 Hal. 137-153; ISSN 20855893. http://ejurnal.iainmataram.ac.id/index.php/beta

Tarhadi, Sugilar \& Sri Lestari Pujiastuti. 2006. Perbandingan Kemampuan Penyelesaian Masalah Matematika Mahasiswa Pendidikan Jarak Jauh dengan Mahasiswa Pendidikan tatap Muka. Jurnal Pendidikan Terbuka dan Jarak Jauh, Voume 7, Nomor 2, September 2006, 121-133. 
Kemampuan Berpikir Logis....(Ety Septiani)

Tuna, Abdulkadir, Abdullah Çağrı Biber,\& Lütfi İncikapı. 2013. An Analysisof Mathematics Teacher Candidates’ Logigal Thinking Levels: Case of Turkey. Journal of Educational and Instructional Studies in the World. February, March, April 2013, Volume: 3 Issue: 1 Article: 10 ISSN: 2146-7463.

Wahyuni, Molli. 2017. Analisis Problematika Perkuliahan Analisis Real. Journal Cendekia: Jurnal Pendidikan Matematika Volume 1, No. 1, Mei 2017. 135149.

Wuryanto. 2011. Meminimalisir Hambatan Belajar Mahasiswa dalam Menyelesaikan Soal Pembuktian Suatu Tautologi Pada Mata Kuliah Analisis Real I dengan Memberdayakan Penalaran yang Berasaskan Prinsip Reductio Ad Absurdum. Kreano: Jurnal Matematika Kreatif-Inovatif. Juni 2011, Volume 2 nomor 1:37-47. 